\title{
Impact of different stocking densities of sheep on establishing stands of Larix sibirica in Iceland
}

\author{
GUĐRÍĐUR BALDVINSDÓTTIR ${ }^{1 *}$, SIGPRÚĐUR JÓNSDÓTTIR ${ }^{2}$ \\ \& BJARNI D. SIGURDSSON ${ }^{1}$ \\ ${ }^{I}$ Agricultural University of Iceland, Hvanneyri, IS-311 Borgarnes, Iceland; ${ }^{2}$ Soil Conservation Service of Iceland, \\ Gunnarsholti, IS-851 Hella, Iceland.*Corresponding author: gugga@lon2.is
}

\begin{abstract}
The present study was the first in Iceland to investigate the effects of different stocking densities of sheep on planted Siberian larch (Larix sibirica) trees. It covered two years and involved four stocking densities in enclosures with $0.1-3.0 \mathrm{~m}$ tall trees, as well as a grazed area on treeless commons. The grazing effect was followed for 75 days each summer. A significant grazing effect was found on the vegetation in both years. None of the sheep stocking densities had a measurable effect on the growth or the survival of the larch trees, however, and no damage was observed on their apical shoots. During the second summer, significant visual and measured browsing effects were recorded on side branches in enclosures with medium and high stocking densities. No trees $<0.5 \mathrm{~m}$ were browsed, however. Siberian larch is generally not sought after by sheep and the results indicated that it may be generally safe to utilize established monoculture Siberian larch stands for sheep grazing during the summer months, if enough other vegetation is present.
\end{abstract}

Keywords: browsing, forest grazing, grazing effect, sheep grazing.

\section{YFIRLIT}

Áhrif mismunandi beitarpunga sauðfjár á ungan lerkiskóg

Dessi rannsókn er sú fyrsta sem gerð er á áhrifum mismunandi beitarpunga sauðfjár á rússalerki (Larix sibirica) á Íslandi. Skoðuð voru áhrif prennskonar beitarpunga á ungan (9-14 ára) lerkiskóg í Kelduhverfi með um priggja metra yfirhæð yfir tvö sumur, en einstök lerkitré voru á bilinu 12 til $301 \mathrm{~cm}$ há. Einnig var beitarfriðuð meðferð í skóginum og beittur afréttur, utan girðingar, mæld. Helstu niðurstöður voru að stýrða beitin hafði mælanleg áhrif á botngróður bæði árin, sem jukust með beitarpunga, en ekki á vöxt né viðgang lerkisins og engar skemmdir mældust á toppsprotum pess eftir tvö sumur. bað fundust pó marktæk beitaráhrif á hliðargreinar trjánna í pungbeitta og meðalbeitta beitarhólfinu seinna sumarið, en aðeins á stærri trjám og engin lerkitré minni en $50 \mathrm{~cm}$ á hæð voru bitin. Rússalerki er almennt ekki eftirsótt af sauðfé og niðurstöður pessarar tilraunar gefa til kynna að óhætt er nýta ungan, óblandaðan lerkiskóg til sumarbeitar, óháð beitarpunga, sem mestur var 0.67 ær á ha. Bent skal á að niðurstöðurnar eiga ekki endilega við vor- eða haustbeit sauðfjár.

\section{INTRODUCTION}

It has been claimed that sheep (Ovis aries L.) grazing has had the greatest impact on vegetation in Iceland since the late ninth century settlement, and that it is the most extensive form of land use until the present (Marteinsdóttir et al. 2017). It may therefore come as a surprise that relatively little research has been conducted on the effect of grazing in the remains of native 
downy birch woodland (Betula pubescens Ehrh.) and afforestation areas in Iceland. One reason is that since organized afforestation with pre-cultivated seedlings began in 1899 in Iceland, enclosing grazing areas has been the main protection to ensure the success of forest establishment (Gunnarsson \& Blöndal 1999). While forest establishment mainly took place on state-owned land, protected from livestock grazing, there was little need for forest grazing research. Since 2000 conditions have changed, as most of the afforestation in Iceland has since been carried out by conventional farmers on their own land (Sigurðsson 2013).

Siberian larch (Larix sibirica Ledeb) is the most common exotic species used for afforestation in Iceland and it is especially dominant in the multiple-purpose forestry in northern and eastern Iceland (Eysteinsson, 2008). During and after the collapse of the economy in Iceland in 2008, afforestation by private landowners decreased, but it is predicted to continue and even increase into the future (Snorrason \& Brynleifsdóttir 2018). Carbon sequestration through afforestation is now becoming relatively important in Iceland and a policy for increased future afforestation efforts are part of Iceland's climate policy (Ministry for the Environment and Natural Resources 2018), and has been found to be among the most costeffective ways that Iceland can reduce its net emissions (University of Iceland Institute of Economic Studies 2017). The Icelandic National Sheep Farmers' Association (2017) has adopted an action plan that includes carbon offsetting of Icelandic sheep farming, where afforestation is part of the planned action. They emphasize the need for further research to examine how carbon offsetting, afforestation and continued sheep grazing can be better integrated on sheep farms in Iceland in order to achieve these goals.

The few studies that have been done on grazing in Icelandic woodlands or within plantation areas have involved both horses (Equus ferus ssp. caballus Boddaert; Pórhallsdóttir \& Brynjólfsson 1993, Halldórsdóttir 2004, Magnúsdóttir 2010,) and sheep (Porsteinsson \& Ólafsson 1967, Porsteinsson et al 1982,
Porsteinsson et al. 1983, Thórhallsdóttir \& Thorsteinsson 1993). However, these have mostly focused on the effect on the animals themselves or on the native downy birch, but no studies have been done looking at the effect of sheep grazing on or affecting the establishment of Siberian larch stands.

Most of the studies that have been conducted on the effects of sheep grazing on forests in neighbouring countries have revolved around native tree species and the grazing effect on their natural regeneration within older forests (Hester et al. 1996, McEvoy et al. 2006, Pollock et al. 2005, Speed et al. 2010). It is therefore difficult to draw direct conclusions from those results and transfer them to afforested areas in Iceland, where seedlings of exotic species are being planted on treeless heathlands.

Limited scientific literature seems to exist about the effects of sheep grazing in larch (Larix sp.) natural forests or plantations. One study has been published from Mongolia (Sankey et al. 2006), where the impact of sheep grazing on planted Siberian larch was investigated in areas where regeneration of native trees had been compromised due to previous goat (Capra aegagrus ssp. hircus Erxleben) over-grazing and where increasing stocking density of goats had enhanced the negative impact on forest renewal. The researchers found that increased stocking density of sheep did not affect the renewal of the Siberian larch in the same way. Experiments have also been conducted in New Zealand on the impact of different sheep stocking density on European larch (Larix decidua Mill) and its palatability, where the tree is considered an invasive exotic species and sheep might be used to suppress it (Ledgard \& Norton 2008). The results indicated that sheep were unlikely to contain the European larch unless the plants were young saplings. The available research therefore seems to indicate that Larix sp. is generally not sought after by sheep.

The objectives of this study were to study the effects of grazing by Icelandic sheep on establishing stands of Siberian larch in $\mathrm{N}$ Iceland. Three different stocking densities during summer were used, along with an 
ungrazed forest control and an adjacent treeless rangeland common with traditional summer grazing. We sought to answer whether it would be possible to utilize Siberian larch stands for sheep grazing during the summer, without unacceptable damage to the trees or loss of forest productivity or tree quality, as well as whether the forest response was dependent on the sheep stocking density.

\section{MATERIALS AND METHODS}

Study area and experimental design

The experimental site was located at the farm Garður in Kelduhverfi, in Norður-Pingeyjarsýsla $\left(66^{\circ} 05^{\prime} 02.4^{\prime \prime} \mathrm{N} 16^{\circ} 47^{\prime} 21.5^{\prime \prime} \mathrm{W}\right)$ in $\mathrm{N}$ Iceland (Fig. 1). The experimental area is located $6 \mathrm{~km}$ inland on a slightly north facing slope at 30-60 $\mathrm{m}$ a.s.1. In 2015 the mean annual air temperature was $3.6{ }^{\circ} \mathrm{C}$, annual precipitation $665 \mathrm{~mm}$, and mean annual wind speed $6.3 \mathrm{~m} \mathrm{~s}^{-1}$. The numbers in 2016 were $4.9^{\circ} \mathrm{C}, 557 \mathrm{~mm}$, and 5.5 $\mathrm{m} \mathrm{s}^{-1}$, respectively (nearby synoptic station at Mánárbakki, Icelandic Meteorological Office). The growing season normally starts in late May and ends in late August. Prior to the afforestation the vegetation was mainly composed of various dwarf shrubs (Betula nana L., Empetrum nigrum L. and Vaccinium sp.) and heather (Calluna vulgaris (L.) Hull), a typical unfertile heathland plant community in NE Iceland used for sheep browsing for centuries. The soils are shallow and of the Brown Andosol type (Arnalds 2015), with occasional lava rocks breaking the surface (Fig. 1). Further description of the experimental area can be found in Baldvinsdóttir (2018).

In 2001-2005 the main experimental area was protected from livestock grazing and planted by Siberian larch (Fig. 1). In spring 2015, when the present experiment was established by making three sheep grazing enclosures with an average area of 8.1 ha, the larch trees were 9-14 years old and varied in height between 12 and $301 \mathrm{~cm}$. The mean tree plantation density was 2087 per ha. The treatments were grazed for 75 days, from the middle of June until mid-September during 2015 and 2016, which were the same periods that the local farmers kept their sheep on the commons in this area of Iceland. The sheep were Icelandic sheep from a nearby farm (Lón 2), ten ewes each year, one-year olds with one lamb each. All were chosen from the same family, but a different family was used each summer.

The grazing treatments included low stocking density (LG; 0.22 ewes ha ${ }^{-1}$ ), medium stocking density (MG; 0.47 ewes ha ${ }^{-1}$ ) and high stocking density (HG; 0.63 ewes ha-1). The two control treatments were ungrazed forest (CC) and an adjacent treeless summer pasture common (CG), where stocking density was estimated at 0.07 ewes $\mathrm{ha}^{-1}$. The stocking density in the experiment was determined in accordance with the experiments of the Icelandic Agricultural Research Institute in the 1970 s in the Kelduhverfi area on the same

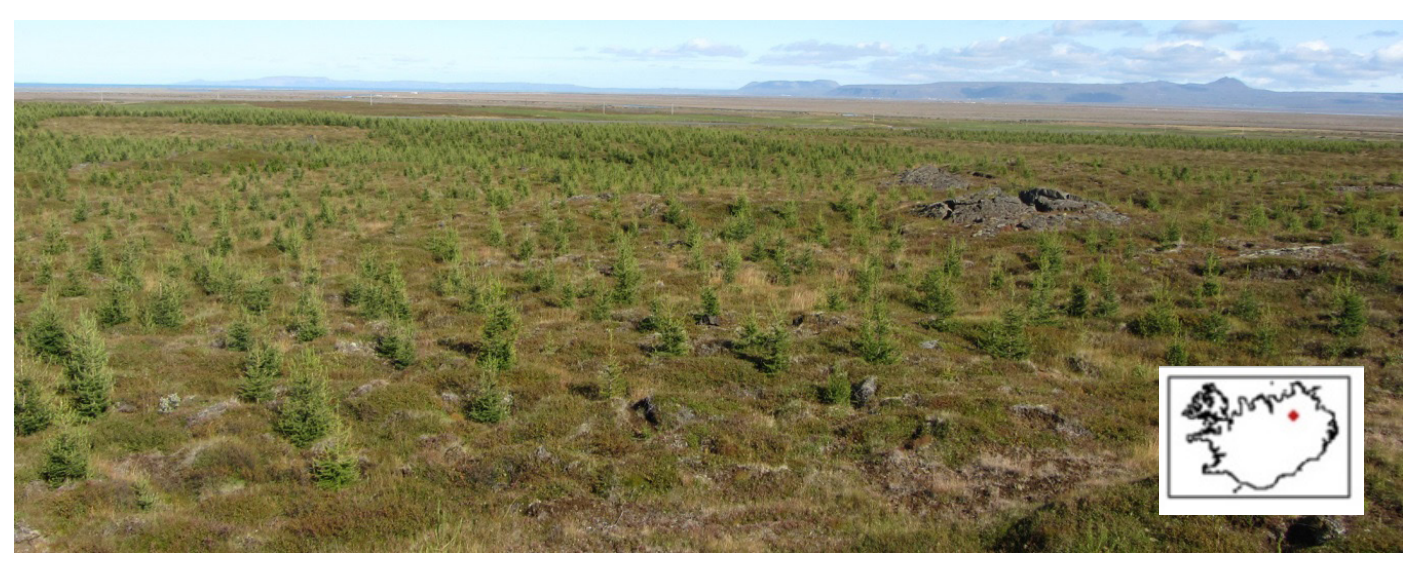

Figure 1. View over the experimental area at the Garður farm in Kelduhverfi. Photo: G. Baldvinsdóttir $4^{\text {th }}$ Sept. 2014. 
vegetation communities, where the stocking densities of $0.55,0.31$ and 0.15 ewes with twin lambs ha-1 were found to give high, medium and low grazing pressure (Porsteinsson 1980). In the present study, large enclosures were preferred to smaller ones with repetitions, to ensure natural grazing behaviour of the Icelandic sheep, which are used to roaming free on the commons during the summer months. Body condition scoring was conducted on all sheep, both ewes and lambs, before and after the grazing period (Russel et al. 1969).

Within each of the four forested treatments, nine $100 \mathrm{~m}^{2}$ circular plots were randomly placed, for tree and vegetation estimates. In the $\mathrm{MG}$ enclosure, three extra random measurement plots were placed, due to the higher heterogeneity of the forest stand there. The number of trees assessed in each treatment were 201, 201, 198 and 202 for the CC, LG, $\mathrm{MG}$, and $\mathrm{HG}$ enclosures, respectively.

Vegetation was assessed at two $1 \mathrm{~m}^{2}$ frames (sub-plots) placed within each $100 \mathrm{~m}^{2}$ forest plot and within nine $100 \mathrm{~m}^{2}$ plots on the treeless commons (CG). Vegetation browsing by sheep was estimated four times during each year; before grazing started and after 25, 50 and 70 days of grazing, respectively, and maximum vegetation height was measured in each corner of the frame each time. The browsing effect within each frame was evaluated by the visual ranking method (Scott 1989). This method is much quicker than other methods but still gives good answers to changes in vegetation (Laliberte et al. 2010). Vegetation surface cover of all species was also estimated visually before grazing and at the end of each summer in all plots. It was estimated in percent in late summer 2015, while it was evaluated with the Braun-Blanquet cover scale (Magnússon \& Svavarsdóttir 2007) on other occasions.

The first forest inventory was done in autumn 2014. Data sampling on all standing trees within the permanent plots was repeated before and after the grazing period in the first and second year, and included measurements of height and the apical shoot length, stem diameter at breast height $(\mathrm{DBH}$; at $130 \mathrm{~cm})$, or at 50 or $10 \mathrm{~cm}$ for smaller trees.
Table 1. Visual estimate scale for browsing damage.

\begin{tabular}{ll}
\hline Score & Visual estimate \\
\hline Apical shoot & \\
0 & Undamaged \\
1 & Browsed
\end{tabular}

\section{Lateral branches or vegetation}

$\begin{array}{ll}0 & \text { No effect } \\ 1 & \text { Little } \\ 2 & \text { Medium } \\ 3 & \text { High }\end{array}$

No browsing damage

Negligible browsing damage Significant browsing damage

Shoots severely damaged from browsing

\section{Stem wounds}

0 None

No wounds

1 Small wound

$<25 \%$ of circumference and only 1 wound

2 Many small wounds

$<25 \%$ of circumference and

$<5$ wounds

3 Severe wound $>25 \%$ of circumference

4 Many severe $>50 \%$ of circumference wounds

5 Ring barking Ring barking

Each tree within every plot was evaluated visually for browsing damage caused by sheep (Table 1). The number of browsed lateral branches out of 30 top branches in each tree was also counted. If the tree had less than 30 branches in total, the total number of branches and browsed ones was recorded.

\section{Data and statistical analyses}

Average basal area (BA) at $50 \mathrm{~cm}$ height was calculated for each plot. Trees that did not reach $50 \mathrm{~cm}$ height $(9.8 \%$ of all trees) were not included in the BA calculation, even if they were scored for browsing. Standing stem volumes of each plot were calculated using the volume equation of Bjarnadóttir et al. (2007) and mean annual increment in each plot was calculated as the annual difference in autumn measurements. For the calculation of browsing damage to trees, tree measurements within each treatment were divided into five height categories: $<50 \mathrm{~cm}$, $50-99 \mathrm{~cm}, 100-149 \mathrm{~cm}, 150-249 \mathrm{~cm}$ and $>249$ $\mathrm{cm}$. The average number of trees in each of 
these height classes were 19, 40, 43, 92 and 6, respectively, at the beginning of the experiment.

SAS/STAT ${ }^{\circledR}$ program, version 7.1 of SAS Enterprise Guide, was used for statistical analysis. All variables measured on a continuous scale were first checked for normality, and if they passed that, then One-Way ANOVA was used to compare treatment means, followed by Fisher's LSD tests for pairwise comparisons when needed. Those variables which did not pass the normality test were analysed further with the non-parametric rank order Kruskal-Wallis test to test treatment differences, followed by the Mann-Whitney U test for pairwise comparisons when needed. The smallest level of significance was set to $\mathrm{P}<0.05$.

\section{RESULTS}

Vegetation

The experimental area was $98 \%$ covered with vegetation (Fig. 1). Out of 104 vegetation subplots surveyed in the middle of the experimental period in August 2015, 102 had 75-100\% vegetation cover. Vascular plant cover was 75 $100 \%$ in 99 sub-plots and the remaining (5) had $50-75 \%$ cover. The average Braun-Blanquet scale values of different surface and vegetation classes were $0.3 \%, 0.4 \%, 1.3 \% 1.5 \%, 2.8 \%$ and $86.5 \%$, of rock, ferns, unvegetated soil, lichens, moss, and vascular plants, respectively (data not shown). None of the vegetation classes differed between the five treatments in August 2015, except that the fern cover (mainly Equisetum pratense Ehrh.) was significantly higher in the ungrazed $\mathrm{CC}(0.7 \%)$ than in the $\mathrm{MG}$ or the HG (both $0.3 \%$ ). The CG and the LG both had intermediate fern cover (both $0.4 \%$ ) and were not significantly different from other treatments (data not shown).

Altogether 49 vascular plant species were recorded in all the sub-plots in 2015 (data not shown). The relative abundance of the 10 most common species was estimated in spring and autumn 2015 and 2016; the five most common vascular plant species were dominant in the vegetation community accounted for about four-fifths of the combined average vegetation cover (77-90\%) in 2015 and the next five

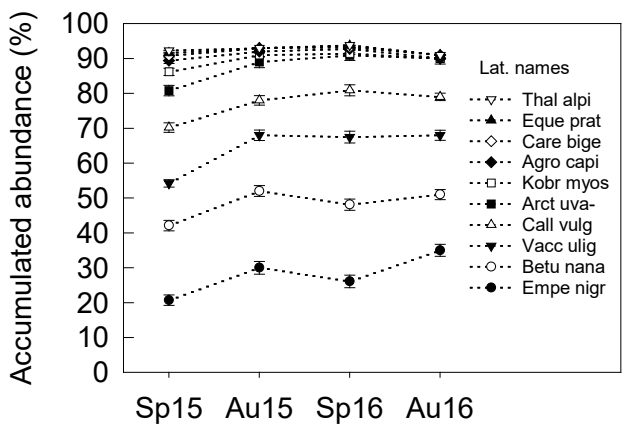

Figure 2. Changes in accumulated relative abundance (\%) of the 10 most common vascular plant species from spring 2015 (Sp15), before the start of the grazing experiment, to autumn 2016 (AU16), at its end. Latin names are indicated as the first four letters in both genera and species names. Values are averages \pm SE of $n=104$ across all treatments.

most common vascular plant accounted for most of the remainder (Fig. 2). No significant differences were detected in the average relative abundance of any of the 10 species between the five different treatments in spring 2016 or in August 2016, indicating that the grazing had not had much effect on plant survival after two years of treatment. The relative vegetation height (compared to the CC treatment) did not change significantly during the experiment (Fig. 3).

However, there were some significant temporal trends, i.e. differences in relative abundance within the same treatment between spring 2015 and 2016 or autumn. Most of those occurred in both ungrazed control and grazed treatments and therefore were not related to the treatments per se (and therefore they also appear in the average trends seen in Fig. 2). The most pronounced was the increasing trend in cover of some of the dwarf bushes, e.g. crowberry ( $E$. nigrum) that was significant in the $\mathrm{HG}$ treatment $(\mathrm{P}=0.03)$ and bog bilberry ( $V$. uliginosum L.) that was significant for the LG treatment $(\mathrm{P}=0.04)$ between spring measurements in 2015 and 2016. The accumulated cover of grasses and sedges generally decreased in grazed treatments in the autumn in 2016 compared to 


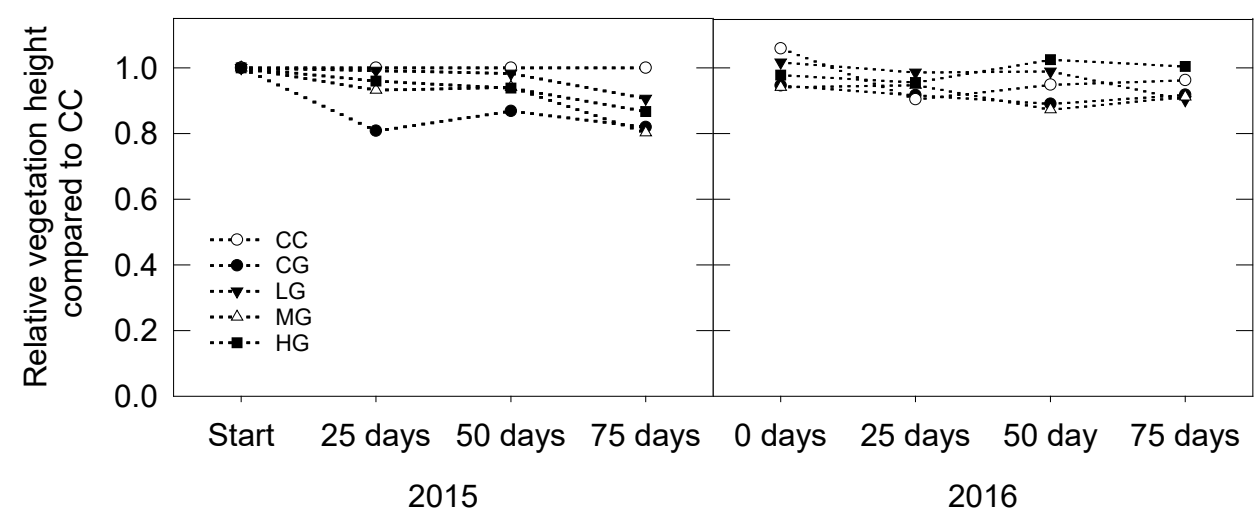

Figure 3. Relative average height of vegetation in 2015 and 2016 in non-grazed forest control (CC), treeless commons pasture (CG), low density forest grazing (LG), medium density forest grazing (MG) and high density forest grazing (HG) by sheep at Garður in NE Iceland. All values are compared to the initial height found in the CC treatment in spring 2015, which then had on average $14.1 \mathrm{~cm}$ vegetation height, and corrected for initial differences in spring 2015. Values are means of 18-24 measurements per treatment.

2015. E.g. Bigelow's sedge (Carex bigelowii Torr. ex Schwein.) had decreased significantly in August 2016 compared to the year before in $\mathrm{MG}(\mathrm{P}=0.003)$, and also Bellard's kobresia (Kobresia myosuroides (Vill.) Fiori) in $\mathrm{HG}$ $(\mathrm{P}=0.05$; data not shown).

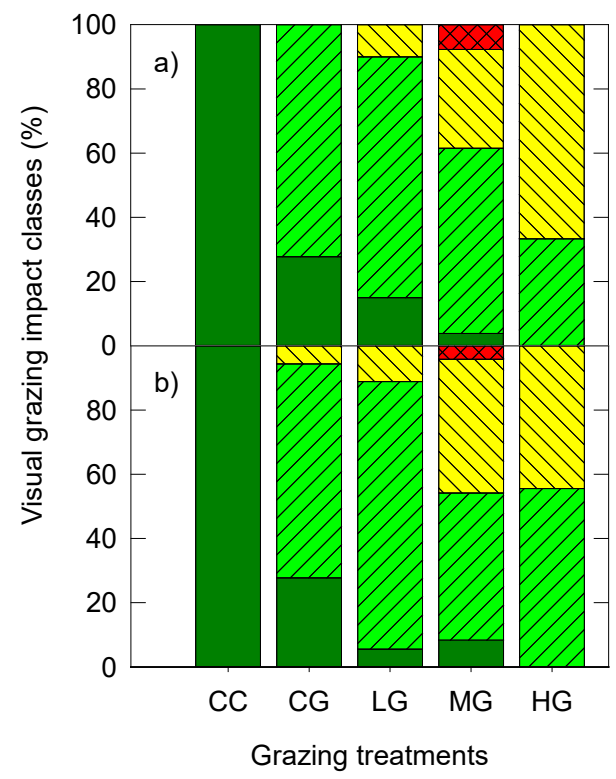

\section{Visual grazing effect}

The grazing had a visible effect on the vegetation of the enclosures, and the proportion of the plots that classified either with 'distinct grazing impact' or 'high grazing impact' increased somewhat regularly with stocking density for both years (Fig. 4). The difference in visible grazing impacts at the end of each summer was statically significant between the ungrazed enclosure and the rest $(\mathrm{P}<0.001)$. The high-density enclosure (HG) also had a highly significant greater visual grazing impact than the LG or the CG in 2015 and the CG in 2016. There was a highly significant difference (always $\mathrm{P}<0.001$ ) between the $\mathrm{LG}$ and $\mathrm{MG}$ enclosures in both years (Fig. 4).

Figure 4. Frequency of visual browsing damage evaluation score of Siberian larch branches (dark green $=$ no browsing; light green = negligible browsing; yellow = distinct browsing; red = severe browsing) in a) August 2015 after one summer (75 days), and b) August 2016 after two summers, in non-grazed forest control (CC), treeless commons pasture (CG), low density forest grazing (LG), medium density forest grazing (MG) and high density forest grazing (HG) by sheep at Garður in NE Iceland. Values are means of 9-12 sub-plots per treatment. 


\section{Tree measurements}

There was no significant difference in mean tree height, height increment of apical shoots, stand basal area or standing stem volume of trees between the treatment plots at the beginning of the experiment (2014; Table 2), indicating that the treatments could be compared during and

2D Graph 5

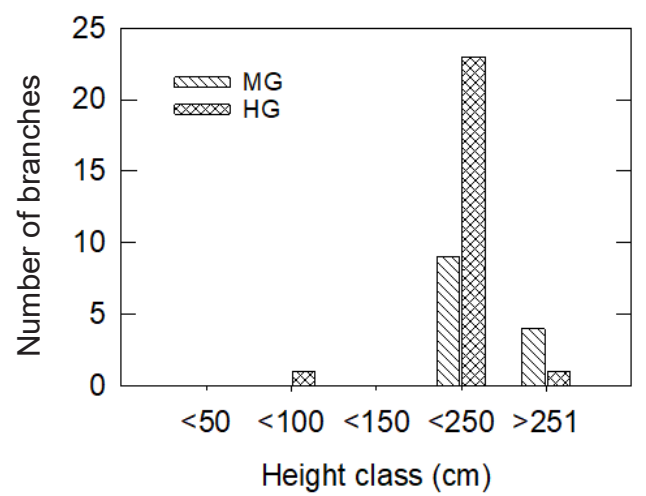

Figure 5. Total number of browsed branches after 50 days in five different height classes of Larix sibirica trees in 2016 (second summer) in medium density forest grazing (MG, left hatched) and high density forest grazing (HG, cross-hatched) by sheep at Garður in NE Iceland. Values are sums for 30 branches surveyed on 198-202 trees per treatment and height class and no. branches where browsed in low density forest grazing (LG). Table 3 shows the grazing intensity after 75 days. after the treatment period to detect any effect of grazing. However, no such grazing effects were detected, neither in autumn 2015 (only shown for HI 2014 in Table 2) nor at the end of the experiment in autumn 2016 (Table 2), and therefore tree height growth, basal area or standing stem volume showed no evidence of being affected by the sheep grazing. The same was found for current annual volume increment (CAI) during both the treatment years (Table 2). However, there was a significant difference in CAI between the two treatment years; CAI was $161 \%$ higher in 2016 than in 2015 across all the treatments, including the ungrazed control (Table 2; $\mathrm{P}<0.001$ ).

\section{Measured tree browsing}

No Siberian larch apical shoots or branches were browsed in 2015, although a total of 601 trees were evaluated in the three grazed enclosures (data not shown). In 2016, no apical shoots were browsed, but some browsed side branches began to appear in the enclosures after 50 days of grazing, particularly in the $\mathrm{HG}$ and MG enclosures (Fig. 5). This was at maximum only $5.5 \%$ of the surveyed trees in the $150-250$ $\mathrm{cm}$ height class and only $0.5 \%$ of surveyed branches. The observed browsing at the end of the experiment, after 75 days, was considerably higher and the $\mathrm{MG}$ and $\mathrm{HG}$ enclosures were significantly $(\mathrm{P}<0.001)$ more browsed than

Table 2. Mean tree height $(\mathrm{H} ; \mathrm{m})$, height increment of apical shoots $\left(\mathrm{HI}, \mathrm{cm}\right.$ year- $\left.{ }^{1}\right)$, basal area $\left(\mathrm{BA}^{*}, \mathrm{~m}^{2}\right.$ ha$\left.{ }^{1}\right)$, standing stem volume $\left(\mathrm{V}, \mathrm{m}^{3} \mathrm{ha}^{-1}\right)$ and current annual increment (CAI, m $\mathrm{ha}^{-1}$ year $\left.{ }^{-1}\right)$ of 9-12 permanent measurement plots surveyed in 2014 (before the experiment started), 2015 (after one summer) and 2016 (after two summers) in non-grazed forest control (CC), low density forest grazing (LG), medium density forest grazing (MG) and high density forest grazing (HG) by sheep at Garður in NE Iceland.

\begin{tabular}{llllllllllll}
\hline Treat. & $\mathrm{H}_{2014}$ & $\mathrm{H}_{2016}$ & $\mathrm{HI}_{2014}$ & $\mathrm{HI}_{2015}$ & $\mathrm{HI}_{2016}$ & $\mathrm{BA}_{2014}$ & $\mathrm{BA}_{2016}$ & $\mathrm{~V}_{2014}$ & $\mathrm{~V}_{2016}$ & $\mathrm{CAI}_{2015}$ & $\mathrm{CAI}_{2016}$ \\
\hline $\mathrm{CC}$ & 1.2 & 1.6 & 33 & 17 & 33 & 1.08 & 2.28 & 0.69 & 1.45 & 0.42 & 1.25 \\
$\mathrm{LG}$ & 1.5 & 1.9 & 37 & 17 & 34 & 1.48 & 2.76 & 0.89 & 1.74 & 0.57 & 1.31 \\
$\mathrm{MG}$ & 1.5 & 1.9 & 37 & 18 & 34 & 1.30 & 2.42 & 0.92 & 1.77 & 0.42 & 1.19 \\
$\mathrm{HG}$ & 1.5 & 1.9 & 35 & 17 & 33 & 1.60 & 3.06 & 0.87 & 1.76 & 0.56 & 1.43 \\
Mean & $\mathbf{1 . 4 1}$ & $\mathbf{1 . 8 3}$ & $\mathbf{3 5 . 8}$ & $\mathbf{1 7 . 1}$ & $\mathbf{3 3 . 4 9}$ & $\mathbf{0 . 0 7}$ & $\mathbf{2 . 6 1}$ & $\mathbf{1 7 . 5}$ & $\mathbf{3 4 . 8}$ & $\mathbf{0 . 4 9}$ & $\mathbf{1 . 2 8}$ \\
P-val. & 0.77 & 0.84 & 0.99 & 0.99 & 0.94 & 0.76 & 0.86 & 0.82 & 0.87 & 0.50 & 0.69 \\
\hline
\end{tabular}

* calculated for diameter at $50 \mathrm{~cm}$ height 
Table 3. Relative amount of browsed trees and branches per tree in five different height classes of Larix sibirica trees after 75 days of grazing in 2016 (second summer) in non-grazed forest control (CC,), low density forest grazing (LG), medium density forest grazing (MG) and high density forest grazing (HG) by sheep at Garður in NE Iceland. Values are sums for 198-202 surveyed trees per treatment and height class.

\begin{tabular}{|c|c|c|c|c|c|c|c|c|}
\hline \multirow[b]{2}{*}{ Height classes } & \multicolumn{2}{|c|}{ Ungrazed } & \multicolumn{2}{|c|}{ Low density } & \multicolumn{2}{|c|}{ Medium density } & \multicolumn{2}{|c|}{ High density } \\
\hline & trees $\%$ & $\begin{array}{l}\text { branches } \\
\text { tree }^{-1}\end{array}$ & trees $\%$ & $\begin{array}{l}\text { branches } \\
\text { tree }^{-1}\end{array}$ & trees $\%$ & $\begin{array}{l}\text { branches } \\
\text { tree }^{-1}\end{array}$ & trees $\%$ & $\begin{array}{l}\text { branches } \\
\text { tree }^{-1}\end{array}$ \\
\hline $0-49$ & 0 & 0 & 0 & 0 & 0 & 0 & 0 & 0 \\
\hline $50-99$ & 0 & 0 & 0 & 0 & 0 & 0 & 4.5 & 1 \\
\hline $100-149$ & 0 & 0 & 2.5 & 1 & 4.5 & 1 & 5.0 & 1 \\
\hline $150-250$ & 0 & 0 & 0 & 0 & 25.8 & 2.3 & 23.1 & 3.2 \\
\hline$>250$ & 0 & 0 & 0 & 0 & 24.5 & 2.5 & 18.8 & 1.8 \\
\hline
\end{tabular}

the CC and LG enclosures (Table 3), but the difference was not significant within those two pairs (MG:HG, $\mathrm{P}=0.91$; CC:LG, $\mathrm{P}=0.32$ ). The browsing was, however, relatively light, even after 75 days in $2016 ; 19-26 \%$ of the $>150 \mathrm{~cm}$ trees had sustained visual browsing signs in the MG and HG enclosures, and on average less than 3.2 branches per tree had been browsed (Table 3).

It was unexpected to find that the sheep avoided browsing the smallest trees; both in the $\mathrm{MG}$ and $\mathrm{HG}$ enclosures the trees $<150 \mathrm{~cm}$ high were highly significantly less browsed (P $<0.001$ ) than higher trees (Table 3). Only in the $\mathrm{HG}$ enclosure did trees under $1 \mathrm{~m}$ sustain any browsing damage. It was also noticeable that browsing damage of trees $>150 \mathrm{~cm}$ normally occurred at a height of $60-80 \mathrm{~cm}$, or approximately at the height of the sheep (data not shown). When examining browsing damage, it was also found that there was no browsing of the current year's shoots; the browsing was constrained to needle bundles on older parts of branches and stems (data not shown).

\section{Visual estimate of tree browsing damage}

Whole tree damage was estimated visually at the end of each summer according to the scale presented in Table 1. No tree crowns (side branches) or apical shoots were scored as 'damaged' at the end of the grazing season in 2015, but two trees had damaged bark (both with one small wound) (data not shown).
At the end of the grazing season 2016, no visual browsing damage was observed on any tree crown in the LG or CC enclosures, but negligible browsing damage was observed in five trees (out of 198 , or $2.5 \%$ of trees) in the MG enclosure and on eight trees (out of 202 trees, $4 \%$ of trees) in the HG enclosure (data not shown). The comparatively little browsing damage in the $\mathrm{MG}$ and $\mathrm{HG}$ enclosures was not significantly different $(\mathrm{P}=0.39)$. Only one tree had damaged bark (with one small wound) in 2016 and no damage was found on apical shoots (data not shown).

\section{Sheep welfare}

Body condition scoring of lambs, before and after the grazing period in 2015 and 2016, did not reveal any statistical differences between treatments (data not shown). No statistical difference was found either for the ewes in 2015 , but in 2016 they were highly significantly fatter after the grazing period in all treatments than in the year before $(\mathrm{P}<0.001)$.

In autumn 2015 the mean body weight of the lambs that were kept in the enclosures was $34.9 \mathrm{~kg}$, compared to $31.5 \mathrm{~kg}$ for 16 living lambs from one-year old ewes that grazed on the commons from the Lón 2 farm (11\% higher from the enclosures; $\mathrm{P}=0.03)$. In autumn 2016 all the lambs from the enclosures were sent to the slaughterhouse on September 15 and their mean carcass weight was $16.5 \mathrm{~kg}$. The mean weight of all other slaughtered lambs of one- 
year old ewes from the Lón 2 farm was 15.7 $\mathrm{kg}$ (5\% higher from the enclosures, but not significantly so), even if part of the flock was not slaughtered until October 20. There were no significant differences in the mean body weight of lambs from the HG and all lambs from the MG and LG enclosures in 2015 or 2016 (data not shown).

\section{DISCUSSION}

The main research question was whether it is possible to utilize a young cultivated Siberian larch monoculture stands for sheep grazing during the summer months, i.e. at the conventional sheep grazing times for grazing commons, without unacceptable forest damage. The answer to that question is unequivocally positive from the results of this study. Siberian larch mortality due to the grazing was zero, and no apical shoot damage was caused by it, regardless of the height of the trees. Bark damage was virtually absent, and side-branch browsing only caused minor crown damage in $<5 \%$ of the trees where the sheep stock density was highest.

The second research question about whether the sheep grazing had either positive or negative effects on tree growth rates and forest productivity also gave decisive responses. No significant effects were seen on tree growth or forest productivity despite intensive measurement effort during two following years.

\section{Effects on vegetation}

The forest in Garður was 9-14 years old at the time of the study, rather sparse, with dense vegetation and therefore well-suited for sheep. The vegetation was still the same vegetation community as was found in the nearby treeless grazed commons. However, vegetation changes in planted forests are inevitable over time, but they will not become substantial until the trees begin to form closed canopies in Siberian larch stands (Elmarsdóttir et al. 2011).

There was a clear visual browsing effect on the vegetation in both years, which increased with the stocking density in the enclosures. It has been found that grazing pressure increases very rapidly in the heathlands in NE Iceland with increasing stocking density due to their low yield (Gudmundsson \& Bement 1986). The effect on the vegetation composition or vegetation height was not significant, however. This is most likely explained by the vegetation community, where dwarf shrubs were dominant. Sheep select plants both vertically and horizontally and prefer to select grasses and herbaceous plants from within the dwarf shrubs, which they avoid if they can (Jónsdóttir 1989; Thórhallsdóttir \& Thorsteinsson 1993). When dwarf shrubs are over four fifths of the relative abundance of species as in the present study, a large vegetation response cannot be expected. Also, even though the forest area had been protected from livestock grazing for 15 years before the present study, the area had been grazed by sheep for a millennium before that. The effect of continued grazing for such long periods, especially if the grazing pressure was substantial, can be that less palatable and poor grazing plants will prevail (Provenza et al. 2003), even if an appropriate stocking density can also be the best way to improve grassland quality in terms of forage composition, especially in an alpine environment (e.g. Pittarello et al. 2019). The site history probably led to this dwarf-shrub vegetation community becoming dominant in the area, and it therefore would take a much longer time to turn it around (Thorsteinsson 1986). This is the situation of most of the heathlands that are being afforested in Iceland today (Thórhallsdóttir \& Thorsteinsson 1993). It is likely that longer experiments than this are therefore needed to achieve a decisive change in vegetation of such grazing-adapted heathlands with high stocking density.

\section{Tree browsing}

The impacts of different stocking densities on the Siberian larch trees were small. It should also be noted that although there was a marked difference in browsing damage in the high and medium stocking density enclosures versus the low stocking density and ungrazed enclosures, this does not necessarily mean that the difference is important for the afforestation. The maximum 
average number of shoots browsed on each tree was ca. three lateral shoots, and among them there were no apical side-shoots. That can hardly be called browsing damage, rather a browsing effect.

One of the most interesting things that came out of this study was that smaller Siberian larch trees were totally unharmed by the sheep. It came as a surprise that sheep did not take the apical shoots that were at a comfortable browsing height. Two alternative explanations could result in such a lack of browsing: a) the current year's shoots of Siberian larch are not palatable during summer, or b) the stocking densities used in the experiment were too low, which allowed for some preferred plants to be available during the whole grazing period. The latter was clearly not the case; even the LG stocking density was considerably higher than the "normal" stocking density in the CG highland commons.

One can also wonder why the sheep almost did not touch the Siberian larch until the latter half of the second grazing period in 2016. Most likely, the cumulative grazing effect on the pasture was the most important factor in this. However, although there was no significant change in the composition of vegetation during the experiment, it is known that plants can respond to initiated grazing by increasing the production of secondary metabolites (Bennett \& Wallsgrove 1994; Agrawal 1998), which could explain why the sheep might have started to browse the more unpalatable Siberian larch trees towards the end of the experiment. It should be noted that sheep of different families were used each year. Plant selection has been shown to be a rather individual trait in Icelandic sheep (Thórhallsdóttir \& Thorsteinsson 1993). However, if the genetic background of the two flocks had an effect, then this should not have appeared only in the higher stocking densities, but rather at random. The last potential influential factor would be the warmer and drier summer of 2016 compared to 2015. This could possibly have caused an earlier wintering of vegetation, thus making the larch more desirable (Nedkvitne \& Garmo 1986; Pettorelli et al. 2007). Such responses of browsing damage are known, as the degree of browsing damage on trees is often linked to availability or palatability of non-woody vegetation (Mitchell et al. 1996). Again, if this had been the case less difference between stocking densities would have been expected.

\section{Implications and further research}

The results of this study only apply for summer grazing in monoculture Siberian larch stands. Hence, the results should not be interpolated to effects of sheep grazing during late autumn, winter, or early spring. After the Siberian larch needles are shed in the autumn, sugars and nutrients accumulate in the bud and under the bark (Furze 2018). It has for example been found that in black cottonwood (Populus trichocarpa (Hook) Torr. \& A.Gray) in Iceland, sheep start to damage its bark just before and after its autumn senescence (Sigurdsson 2013). Further, studies have shown that the aged vegetation in autumn and winter makes small tree plants more visible and increases the likelihood of damage (Hester et al. 1996), and also that woody plants are both more juicy and more accessible to sheep in winter than other plants (Porsteinsson \& Ólafsson 1967).

Since no stem apical shoots nor branchapical shoots were browsed in either year, the visual and economical browsing effect on the Siberian larch was negligible. More and more farmers in Iceland are now asking when it is safe to reintroduce livestock to afforested areas without causing unacceptable damage to the trees. There is still a lack of such research in Iceland, as has repeatedly been pointed out (Óladóttir et al. 2003, Sigurðsson 2013). Further research should therefore be focused on the impact of sheep grazing on different tree species in different seasons. Such studies should preferably also be done with different stocking densities (Halldórsdóttir 2004; Magnúsdóttir 2010). Future research in Iceland should focus both on the impact on forest renewal and on whether and when it is age-, size- and timewise safe to graze our forests. Before more knowledge has been accumulated, there is no reliable guide on how forestry and grazing can 
go together without unacceptable damage to trees. Reliable data on sheep grazing research are most urgent, as sheep grazing is the most extensive use of heathlands at the national level in Iceland (Marteinsdóttir et al. 2017).

\section{CONCLUSIONS}

Siberian larch is generally not preferred by sheep, but the results of this experiment showed that it was safe to graze sheep in young monoculture Siberian larch stands that ranged from $10 \mathrm{~cm}$ to $3 \mathrm{~m}$ in height during the summer months, irrespective of the stocking density of sheep, which was at most 0.67 ewes ha $^{-1}$.

Since the the diffrent stock density treatments did not affect the sheep performance or tree responses it was not possible to confirm maximum stocking density that the forest can tolerate.

It is important to note that the present results apply only to summer grazing. Further research is needed before it can be asserted that spring, autumn or winter grazing can be recommended in monoculture Siberian larch stands. However, active grazing management is always necessary to ensure the wellbeing of both the grazing animals and the pasture; and even more-so in a forest pasture, where the browsing behaviour of sheep must be carefully monitored and intervened in, if needed.

This was the first organized study to be carried out in Iceland on the effects of sheep grazing on Siberian larch. There is therefore a great need for continued research in this area, and thus to seek ways to better integrate these two land-use methods, sheep farming and forestry, which have hitherto been considered almost incompatible in Iceland.

Forest damage is a relative term; it can be emotional, aesthetical, or financial. It is necessary to make a clear distinction between these factors.

\section{ACKNOWLEDGEMENTS}

The Icelandic Sheep Productivity Fund supported the study. We would also like to thank Hrund Ásgeirsdóttir and Rúnar Tryggvason, owners of the forested study area, for lending it to us. This work is a contribution to the Nordic CAR-ES project.

\section{REFERENCES}

AgrawalAA1998. Induced responses to herbivory and increased plant performance. Science 279(5354), 1201-1202.

https://doi.org/10.1126/science.279.5354.1201.

Arnalds Ó 2015. The Soils of Iceland. Springer.

Baldvinsdóttir G 2018. Áhrif mismunandi beitarpunga sauðfjár á ungan lerkiskóg og viðhorf skógar- og sauðfjárbænda til skógarbeitar [M.Sc. thesis]. [Impact of different stocking rates of sheep on establishing stands of Larix sibirica and views of Icelandic sheep and forest-farmers towards forest grazing]. Agricultural University of Iceland. Accessed 15.07.2019 at http://hdl.handle. net/1946/30719. [In Icelandic, English summary].

Bennett RN \& Wallsgrove R-M 1994. Secondary metabolites in plant defence mechanisms. New Phytologist 127(4), 617-633.

https://doi.org 10.1111/j.1469-8137.1994.tb02968.x.

Bjarnadóttir B, Inghammar AC, Brinker MM \& Sigurðsson BD 2007. Single tree biomass and volume functions for young Siberian larch trees (Larix sibirica) in eastern Iceland. Icelandic Agricultural Sciences 20, 125-135.

Elmarsdóttir E, Sigurðsson BD, Oddsdóttir ES, Fjellberg A, Guðleifsson BE, Magnússon B, Ólafsson E, Halldórsson G, Guðmundsson GA, Eyjólfsdóttir GG, Skarphéðinsson KH, Ingimarsdóttir M \& Nielsen ÓK 2011. Áhrif skógræktar á tegundaauðgi. [Effects of afforestation on biodiversity]. Náttúrufræðingurinn 81(2), 6981. [In Icelandic, English summary].

Eysteinsson P 2008. Innfluttu skógartrén V. Rússalerki (Larix sukaczewii Dylis). [Imported tree species V. Siberian larch]. Skógrcektarritið 2008(1), 20-39. [In Icelandic].

Furze ME 2018. Seasonal patterns of nonstructural carbohydrate reserves in four woody boreal species. The Journal of the Torrey Botanical Society 145(4), 332-339.

https://doi.org/10.3159/TORREY-D-18-00007.1

Gudmundsson O \& Bement RE 1986. Grazing intensity and balancing animal numbers with forage resources: Sheep responses under subarctic conditions. In: Gudmundsson O (ed.) Grazing 
Research at Northern Latitudes, NATO Advanced Science Institutes Series: Series A: Life sciences (USA), 108, 311-322.

Gunnarsson SB \& Blöndal S 1999. Íslandsskógar: hundrað ára saga. [Icelandic forests: Hundred years of history]. Reykjavík: Mál og mynd. [In Icelandic].

Halldórsdóttir SA 2004. Hrossabeit í skógræktargirðingu. [Horses grazing in an afforested area]. [B.Sc. thesis]. Icelandic Agricultural University. Accessed 22.04.2018, Apríl 2018 at http://hdl.handle.net/1946/7555. [In Icelandic].

Hester AJ, Mitchell FJ \& Kirby KJ 1996. Effects of season and intensity of sheep grazing on tree regeneration in a British upland woodland. Forest Ecology and Management 88(1-2), 99-106. https://doi.org/10.1016/S0378-1127(96)03815-7.

Jónsdóttir S 1989. Beitaratferli og plöntuval sauðfjár og hrossa. [Behaviour and plant selection of sheep and horses]. Ráðunautafundur 1989, 133-140. [In Icelandic].

Laliberte E, Norton DA, Tylianakis JM \& Scott D 2010. Comparison of Two Sampling Methods for Quantifying Changes in Vegetation Composition Under Rangeland Development. Rangeland Ecology and Management 63(5), 537-545. https:// doi.org/10.2111/REM-D-09-00156.1.

Ledgard N \& Norton D 2008. The impact of browsing on wilding conifers in the South Island high country. New Zealand Journal of Forestry 52(4), 29.

Magnúsdóttir L 2010. Áhrif hrossabeitar á vöxt, útlit og lifun birkis. [Effects of horse grazing on growth, appearance and survival of downy birch]. [B.Sc. thesis]. Agricultural University of Iceland. Accessed 15.10.2017 at http://hdl.handle. net/1946/7934. [In Icelandic].

Magnússon SH \& Svavarsdóttir K 2007. Áhrif beitarfriðunar á framvindu gróðurs og jarðvegs á lítt grónu landi. [Effects of excluding sheep on vegetation succession and soil in an eroded area] Fjölrit Náttúrufrceðistofnunar 49, 67 p. [In Icelandic].

Marteinsdóttir B, Barrio IC, Jónsdóttir IS 2017. Assessing the ecological impacts of extensive sheep grazing in Iceland. Icelandic Agricultural Sciences 30, 55-72.
McEvoy PM, McAdam JH, Mosquera-Losada M \& Rigueiro-Rodriguez A 2006. Tree regeneration and sapling damage of pedunculate oak (Quercus robur) in a grazed forest in Galicia, NW Spain: A comparison of continuous and rotational grazing systems. Agroforestry Systems 66(2), 85-92.

https://doi.org/10.1007/s10457-005-2916-0.

Ministry for the Environment and Natural Resources 2018. Aðgerðaácetlun í loftslagsmálum 2018 - 2030. [Iceland's climate action plan for the period 2018-2030]. Ministry for the Environment and Natural Resources: Reykjavik, 44 pp. [In Icelandic].

Mitchell FJ, Hester AJ \& Kirby KJ 1996. Effects of season and intensity of sheep grazing on a British upland woodland: Browsing damage to planted saplings. Botanical Journal of Scotland 48(2), 199207.

https://doi.org/10.1080/03746609608684841.

National Sheep Farmers' Association 2017. Kolefnisjöfnun islenskrar sauðfjárrræktarAðgerðaáætlun. [Carbon offsets for Icelandic sheep farms]. Accessed 14.04.2018 at http:// www.saudfe.is/images/A \% C3\%B 0 ger $\%$ C $3 \%$ B 0 a $\%$ C $3 \%$ A $1 \%$ C $3 \%$ A 6 tlun_um_kole fnisj \%C3\%B f fnun_\%C3\%ADslenskrar_ sau\%C3\%B0fj\%C3\%A1rr\%C3\%A6ktar.pdf. [In Icelandic].

Nedkvitne JJ, \& Garmo TH 1986. Conifer woodland as summer grazing for sheep. In: Gudmundsson O (ed.) Grazing Research at Northern Latitudes, NATO Advanced Science Institutes Series: Series A: Life sciences (USA), 108, 121-128.

Óladóttir A, Jónsson K \& Porvaldsson SK 2003. Skógrækt bænda, hvernig og til hvers? [Afforestation by farmers: How and what for?]. Freyr 6/2003, 30-39. [In Icelandic].

Pettorelli N, Pelletier F, von Hardenberg A, FestaBianchet M \& Cote SD 2007. Early onset of vegetation growth vs. rapid green-up: Impacts on juvenile mountain ungulates. Ecology 88(2), 381-390. https://doi.org/10.1890/06-0875.

Pittarello M, Probo M, Perotti E, Lonati M, Lombardi G, Enri SR 2019. Grazing Management Plans improve pasture selection by cattle and forage quality in sub-alpine and alpine grasslands. Journal of Mountain Science 16, 2126-2135. https://doi.org/10.1007/s11629-019-5522-8 
Pollock ML, Milner JM, Waterhouse A, Holland JP \& Legg CJ 2005. Impacts of livestock in regenerating upland birch woodlands in Scotland. Biological Conservation 123(4), 443-452.

https://doi.org/10.1016/j.biocon.2005.01.006.

Provenza FD, Villalba JJ, Dziba LE, Atwood SB \& Banner RE 2003. Linking herbivore experience, varied diets, and plant biochemical diversity. Small Ruminant Research 49(3), 257-274.

https://doi.org/10.1016/S0921-4488(03)00143-3.

Russel AJF, Doney JM \& Gunn RG 1969. Subjective assessment of body fat in live sheep. The Journal of Agricultural Science, 72(3), 451-454.

Sankey T T, Montagne C, Graumlich L, Lawrence R \& Nielsen J 2006. Lower forest-grassland ecotones and 20th Century livestock herbivory effects in northern Mongolia. Forest Ecology and Management 233(1), 36-44.

https://doi.org/10.1016/j.foreco.2006.05.070.

Scott D 1989. Description of vegetation using visual ranking of species. New Zealand Journal of Ecology, 12, 77-88.

Sigurðsson BD 2013. Sauðfjárbeit í skóglendi Íslands: Ný viðhorf. [Sheep grazing in Icelandic forests: New attitudes]. In: Sigurðardóttir R (ed.). Sauðfjárrcekt á Íslandi. Alhliða frceðslurit um islenskt sauðfé og sauðfjárrcekt fyrr og nú með leiðbeinandi efni um hagkvoema og góða búskaparhcetti (pp. 135-143). Reykjavík: Uppheimar. [In Icelandic].

Snorrason A \& Brynleifsdóttir SJ 2018. Áhrif fjórföldunar nýskógræktar á Íslandi [The impact of increasing afforestation fourfold]. Skógrcektarritið 2018(1), 34-45. [In Icelandic].

Speed JDM, Austurheim G, Hester AJ \& Mysterud A 2010. Experimental evidence for herbivore limitation of the treeline. Ecology 91(11), 34143420 .

https://doi.org/10.1890/09-2300.1.

Thorsteinsson I 1986. The effect of grazing on stability and development of northern rangelands: A case study of Iceland. In: Gudmundsson O (ed.) Grazing Research at Northern Latitudes, NATO Advanced Science Institutes Series: Series A: Life sciences (USA), 108, 37-43.

Thórhallsdóttir AG \& Thorsteinsson 1993. Behaviour and plant selection. Icelandic Agricultural Sciences 7, 57-77.
University of Iceland Institute of Economic Studies 2017. Skýrsla nr. C17:01, Ísland og loftslagsmál. [Iceland and Climate issues]. Reykjavík: Höfundur. [In Icelandic].

Porsteinsson I \& Ólafsson G 1967. Beitartilraun í Hallormsstaðaskógi. [Grazing experiment in Hallormsstaðaskógur forest]. Ársrit Skógrcektarfélags Íslands 1967, 6-14. [In Icelandic].

Porsteinsson I 1980. Gildi úthagans og beitarpolsrannsóknir.[Range resources and grazing intensity research]. Íslenskar Landbúnaðarrannsóknir 12(2), 5-10. [In Icelandic].

porsteinsson I, porgeirsson S \& Thorsteinsson SS 1982. Fjárbeit í skógi [Sheep grazing in a forest]. Ársrit Skógræktarfélags Íslands 1988, 55. [In Icelandic].

Porsteinsson I, Loftsson J \& Guðmundsson Ó 1983. Beitartilraun í Hallormsstaðaskógi. [Grazing experiment in Hallormsstaðaskógur forest]. Ársrit Skógræktarfélags Íslands 1983, 25-32. [In Icelandic].

Pórhallsdóttir AG \& Brynjólfsson R 1993. Hrossabeit í skógræktargirðingu. [Horse grazing in an afforested area] In: Sigursveinsson R (ed.) Rit búvísindadeildar. Tilraunaskýrsla Bcendaskólans á Hvanneyri 1992 (18-19). [In Icelandic].

Manuscript received 21.3.2020 Accepted 1.9.2020 